\title{
Optimizing cropland cover for stable food production in Sub-Saharan Africa using simulated yield and Modern Portfolio Theory
}

\author{
P. Bodin ${ }^{1}$, S. Olin ${ }^{1}$, T. A. M. Pugh ${ }^{2}$, and A. Arneth ${ }^{2}$ \\ ${ }^{1}$ Department of Physical Geography and Ecosystem Science, Lund University, Lund, Sweden \\ ${ }^{2}$ Institute of Meteorology and Climate Research, Atmospheric Environmental Research, \\ Karlsruhe Institute of Technology, Garmisch-Partenkirchen, Germany \\ Received: 14 October 2014 - Accepted: 6 November 2014 - Published: 5 December 2014 \\ Correspondence to: P. Bodin (per.e.bodin@gmail.com) \\ Published by Copernicus Publications on behalf of the European Geosciences Union.
}

Optimizing cropland cover for stable food production in Sub-Saharan Africa

P. Bodin et al.

Title Page

Abstract Introduction

Conclusions

References

Tables

Figures

14

4

Back

$\Delta$

$\checkmark$

Close

Full Screen / Esc

Printer-friendly Version

Interactive Discussion 


\section{Abstract}

Food security can be defined as stable access to food of good nutritional quality. In Sub Saharan Africa access to food is strongly linked to local food production and the capacity to generate enough calories to sustain the local population. Therefore it is im5 portant in these regions to generate not only sufficiently high yields but also to reduce interannual variability in food production. Traditionally, climate impact simulation studies have focused on factors that underlie maximum productivity ignoring the variability in yield. By using Modern Portfolio Theory, a method stemming from economics, we here calculate optimum current and future crop selection that maintain current yield while tizing variance, vs. maintaining variance while maximizing yield. Based on simulated yield using the LPJ-GUESS dynamic vegetation model, the results show that current cropland distribution for many crops is close to these optimum distributions. Even so, the optimizations displayed substantial potential to either increase food production and/or to decrease its variance regionally. Our approach can also be seen as

15 a method to create future scenarios for the sown areas of crops in regions where local food production is important for food security.

\section{Introduction}

Global food security is a fundamental challenge for Earth's current and future population. Currently 842 million people in the world are under-nourished (Food and Agricultural Organisation, 2013). Food security is linked to food production, access to food via local to global markets, the stability of this access, and the nutritional quality and safety of food (Webber et al., 2014). In many regions of the world, people are largely dependent on local food production, and in Sub-Saharan Africa (SSA) crop production makes up a large part of people's income, with roughly $17 \%$ of GDP coming from agriculture in 2005 (World Bank, 2007).
ESDD

$5,1571-1606,2014$

Optimizing cropland cover for stable food production in Sub-Saharan Africa

P. Bodin et al.

\section{Title Page}

Abstract Introduction

Conclusions References

Tables Figures

14

4

Back

Full Screen / Esc

Printer-friendly Version

Interactive Discussion 
Due to an increasing global population and changing food consumption patterns, it is expected that food production needs to double by 2050 (Foley et al., 2011). Two main options exist for achieving this enhanced production: increasing the extent of agricultural land, or increasing food production on existing crop land. One way to achieve the 5 latter is by reducing the difference between actual and potential yield (i.e. closing the yield gap) through improved management (including irrigation and fertilizer use) and by varietal selection (Foley et al., 2011). Another option is selection for crop types and it has been estimated that global cereal crop production could increase by $46 \%$ by always selecting the most productive cereal for each location (Koh et al., 2013).

10 Food production is closely linked to climate, and in absence of major progress in breeding the effects of climate change on agriculture will be most adverse in regions which already today suffer from high temperatures and low precipitation, and where these are projected to worsen. SSA is one such region (Barrios et al., 2008) with around $97 \%$ of cropland area being rain-fed (Rockström et al., 2004) further amplifying the 15 sensitivity of agriculture to precipitation. Expected increases in temperature for SSA range from 2.0 to $4.5^{\circ} \mathrm{C}$ by 2100 (Müller, 2009) while annual precipitation for individual countries in Africa is expected to change by -39 to $+64 \mathrm{~mm}$ by 2030 (Jarvis et al., 2012). Yields for the African continent have been estimated to decline on average by $-7.7 \%$ by 2050 , with the effect on yields for wheat and sorghum being -17.2 and $20-14.2 \%$ respectively (Knox et al., 2012).

Different approaches have been used to estimate future crop yield and variability. At the continental to global scale, agricultural models have been applied to simulate future crop yield (Berg et al., 2011; Bondeau et al., 2007; Deryng et al., 2011; Di Vittorio et al., 2010; Gervois et al., 2004; Lokupitiya et al., 2009; Sus et al., 2010; Tao et al., 2009; Lindeskog et al., 2013). Many of these models have been applied within the Agricultural Model Intercomparison and Improvement Project (AgMIP) (Rosenzweig et al., 2013) which includes a large model intercomparison study of the effect of global change on future crop yield globally (Rosenzweig et al., 2014). Studies using this type of models have mainly addressed the impact of climate on mean yield, but some studies have
ESDD

$5,1571-1606,2014$

\section{Optimizing cropland cover for stable food production in Sub-Saharan Africa \\ P. Bodin et al.}

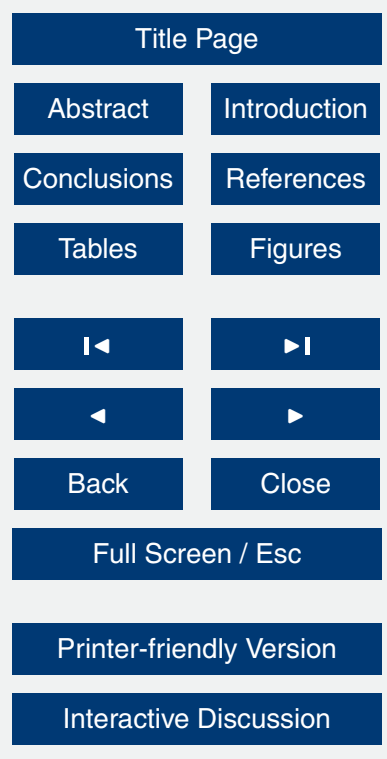


also investigated the effect of climate change on changes in yield variability (Chavas et al., 2009; Urban et al., 2012). In the context of future changes in yield and variability, a key question is whether farmers will adapt to climate change by optimizing productivity, or if they will adopt more risk averse management strategies (Matthews 5 et al., 2013). Despite often being described as tools to support adaptation strategies, relatively few examples of crop models being applied to these questions can be found in the literature (Webber et al., 2014). The main focus of existing studies have mostly been on generating response functions to climate and management, or on identifying knowledge gaps at a local-to-regional scale (Webber et al., 2014). To the best of our 10 knowledge no simulation study has been made looking at the adaption potential of crop selection at a continental scale.

One approach to identify potentials for maximizing production or minimizing risk is by applying Modern Portfolio Theory (Markowitz, 1959) to the selection of crops (fraction of total cropland cover) in order to maximize yield of a portfolio of crops whilst 15 minimizing its variance. This approach has previously been applied to questions such as optimal selection of crop varieties to increase profitability of rice production (Nalley et al., 2009), or how to increase stability in wheat yield (Nalley and Barkley, 2010) at a regional level using data from field trials at experimental sites. Having been tested for observed yield at a regional scale for different varieties of the same crop, we here extended the MPT analysis to include several crops, using simulated current and future yields for all agricultural land in SSA. The analysis was made for seven crops or groups of crops (represented by crop functional types, CFTs, see Methods) for three averaged time periods (1996-2005, 2056-2065 and 2081-2090) in SSA. Simulations were made using the cropland version of the dynamic global vegetation model LPJ-GUESS (GCMs) under one Representative Concentration Pathway (RCP 6.0) (Meinshausen et al., 2011). RCP 6.0 was selected as it is one of two "middle of the road" climate scenarios. The simulations were made at $0.5^{\circ}$ spatial resolution, modeling annual yield for each CFT and grid cell for the time period 1920-2099. To take into account spatial

ESDD

5, 1571-1606, 2014

Optimizing cropland cover for stable food production in Sub-Saharan Africa

P. Bodin et al.

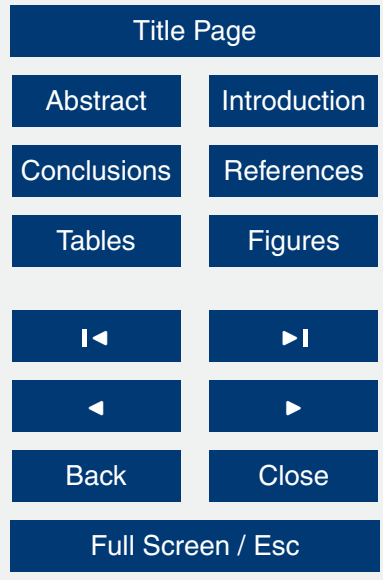

Printer-friendly Version

Interactive Discussion 
differences in management (e.g. application of nutrients and variety selection) simulated yield was normalized by observed yields. In this study we chose to focus on SSA, a region where local subsistence farming is dominating, and simulated crop yield was therefore normalized against data representing this type of farming system.

Crop yield averaged over all CFTs was maximized or its variance minimized using MPT, and combinations of crop distributions fulfilling the criteria for three optimization strategies were selected. The two MPT optimization strategies can be interpreted to represent one risk aversion option $\left(\mathrm{Opt}_{\mathrm{v}, \min }\right)$ and one for yield maximization $\left(\mathrm{Opt}_{\mathrm{y}, \max }\right)$. In addition to the two optimization strategies suggested in MPT, we also applied a third, 10 more straightforward optimization $\left(\mathrm{Opt}_{\mathrm{s}, \mathrm{crop}}\right)$, by selecting the single crop that produced the highest yield in a given location over a specified time period. For future climate the optimizations were made in relation to the current situation thus generating two "whatif" type of scenarios assuming no change in future yield $\left(O p t_{v, \min }\right)$ or variance $\left(\mathrm{Opt}_{\mathrm{y}, \max }\right)$ compared to the present situation.

15 From the optimizations using current or future climate we get new sets of optimum crop distributions. For current climate these new crop distributions were compared to actual crop distributions to look at similarities and differences between the two. The changes in the relative crop distributions over time for the three optimization options were also analysed.

\section{Methods}

\subsection{Model description}

LPJ-GUESS is a process-based dynamic global vegetation model designed to simulate patterns and dynamics of natural vegetation patterns and corresponding fluxes of carbon and water (Smith et al., 2001; Sitch et al., 2003). The model has been described and applied in numerous studies (Morales et al., 2005; Hickler et al., 2004, 2008; Wramneby et al., 2008; Ahlström et al., 2012).
ESDD

5, 1571-1606, 2014

Optimizing cropland cover for stable food production in Sub-Saharan Africa

P. Bodin et al.

\section{Title Page}

Abstract Introduction

Conclusions References

Tables Figures

14

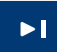

4

Back

Full Screen / Esc

Printer-friendly Version

Interactive Discussion 
Cropland processes were introduced into LPJ-GUESS (Lindeskog et al., 2013), building on the approach by Bondeau et al. (2007) with crops represented through 11 typologies of crops named Crop Functional Types (CFTs). New features in LPJ-GUESS compared to Bondeau et al. (2007) include a phenology scheme where LAI and leaf 5 carbon are coupled at a daily time step. Carbon allocation is dependent on heat unit sums also calculated at a daily time step. A dynamic Potential Heat Unit (PHU) sum needed to reach full maturity is calculated for each grid cell based on the mean temperature of the last 10 years. A new sowing algorithm based on Waha et al. (2012) was also introduced where the timing of sowing depends on temperature or precipitation.

10 Yields of CFTs are simulated separately for irrigated and rain fed crops. Except for sowing and irrigation crops are assumed to be grown under similar conditions regarding management, nutrients and pests thereby simulating a yield that is closer to potential rather than actual yield.

\subsection{Modelling crop yield using LPJ-GUESS}

15 As a part of the Agricultural Model Intercomparison and Improvement Project (AgMIP) (Rosenzweig et al., 2013) a crop model intercomparison study (Rosenzweig et al., 2014) across a range of models was carried out. All models were driven by bias corrected climate forcing data from 5 General Circulation Models (GCMs) (GFDLESM2M, HadGEM2-ES, IPSL-CM5A-LR, MIROC-ESM-CHEM, NorESM1-M) obtained 20 from the Coupled Model Intercomparison Project Phase 5 (CMIP5) archive (Taylor et al., 2012). Simulated rain fed yield from the LPJ-GUESS model runs from this intercomparison study were used here. Seven CFTs were applied in this analysis for SSA $\left(<15.5^{\circ} \mathrm{N}\right)$ : Temperate Winter Wheat (TeWW: representing wheat, barley, oats and rye), Corn/Maize (TeCo), Sugar beet (TeSb: representing also - and in SSA mainly 25 - potatoes and sweet potatoes), and Pulses (TePu); and Tropical Maniok/Cassava (TrMa), Millet (TrMi: including Sorghum) and Rice (TrRi) (Table 1). In this paper we focused on the results from one Representative Concentration Pathway (RCP 6.0)
ESDD

5, 1571-1606, 2014

\section{Optimizing cropland cover for stable food production in Sub-Saharan Africa \\ P. Bodin et al.}

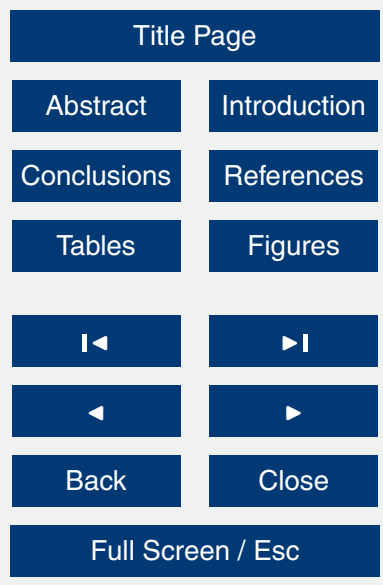

Printer-friendly Version

Interactive Discussion 
(Meinshausen et al., 2011) analysing the results for current (1996-2005) and two future climates (2056-2065 and 2081-2090).

\subsection{Normalizing simulated yield to observed values}

As the model simulates yield that is closely related to potential yield $\left(Y_{p, c} \mathrm{~kg} \mathrm{~m}^{-2}\right)$ for 5 each CFT $(c)$ and year $(y)$, values were normalized to create a simulated actual yield $\left(Y_{n, c} \mathrm{~kg} \mathrm{~m}^{-2}\right)$. This was done by first calculating a yield gap $\left(\mathrm{YG}_{c}\right)$ value for each CFT and grid cell:

$\mathrm{YG}_{C}=1-\frac{Y_{\text {current }, o, c}}{Y_{\text {current }, p, c}}$

where $Y_{\text {current, } p, c}\left(\mathrm{~kg} \mathrm{~m}^{-2}\right.$ in wet weight) was the mean simulated $Y_{n, c}\left(\mathrm{~kg} \mathrm{~m}^{-2}\right.$ in wet 10 weight) for the time period $1996-2005$ and $Y_{\text {current, }, c}\left(\mathrm{kgm}^{-2}\right.$ in wet weight) the actual observed yield for the year 2000. LPJ-GUESS simulates yield measured as dry weight, and values were therefore converted into wet weight by using crop specific values for grain/tuber water content (Wirsenius, 2000). Values for $Y_{\text {current, }, c, c}$ were taken from the SPAM database (You et al., 2013). The SPAM dataset is a gridded dataset 15 of crop production and area compiled from a range of datasets and disaggregated to a 5 arc-minute spatial resolution. As the spatial resolution of LPJ-GUESS is $0.5^{\circ}$ we aggregated the SPAM dataset to the same spatial resolution. SPAM reports yield separately for high and low input of nutrients as well as subsistence farming. The latter type of farming can be said to be dominating for most parts of SSA and was there-

\section{ESDD}

$5,1571-1606,2014$

\section{Optimizing cropland cover for stable food production in Sub-Saharan Africa \\ P. Bodin et al.}

\section{Title Page}

Abstract Introduction

Conclusions References

Tables Figures

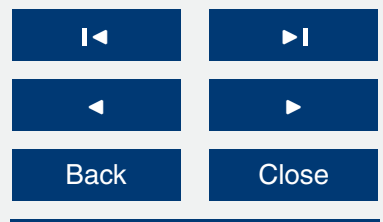

Full Screen / Esc

Printer-friendly Version

Interactive Discussion getting unrealistically large or small values of $Y G_{C}$ we excluded CFTs from this analysis if either $Y_{\text {current }, O, c}$ or $Y_{\text {current, },, c}$ were zero or close to zero $\left(<0.01 \mathrm{~kg} \mathrm{~m}^{-2}\right)$. For these grid cells we instead assigned a "gap-filled" yield gap value $\left(\mathrm{YG}_{\mathrm{gap}, c}\right)$ based on a 
distance weighted interpolation using yield data from grid cells that are within the same agro-ecological zone (AEZ) (Fischer et al., 2012) for the year 2000:

$\mathrm{YG}_{\mathrm{gap}, c}=\frac{\sum_{i=1}^{N} \frac{\mathrm{YG}_{c, i}}{d_{i}}}{\sum_{i=1}^{N} \frac{1}{d_{i}}}$

where $d_{i}$ is the distance (in degrees) between cell $j$ (the grid cell for which $Y G_{\text {gap }, c}$ is 5 calculated) and any cell $i$ belonging to the same AEZ as grid cell $j . N$ is the number of grid cells belonging to the same AEZ as cell $j$. To avoid an unrealistically large spread of some crops a CFT was not allowed to expand into areas located further away than $2.5^{\circ}$ from where they currently are grown.

Simulated normalized annual yield $\left(Y_{n, c}\right.$ in $\mathrm{kg} \mathrm{m}^{-2}$ wet weight) for each year was 10 calculated using Eq. (1) and by substituting $Y_{\text {current,o,c }}$ with $Y_{n, c}$ and $Y_{\text {current, }, c}$ with $Y_{p, c}$. If $Y G_{c}$ was $0 Y G_{\text {gap }, c}$ was further substituted for $Y G_{c} . Y_{n, c}$ was converted from kg m${ }^{-2}$ to $\mathrm{kcal} \mathrm{m}^{-2}\left(Y_{\mathrm{cal}, c}\right)$ by using values for calorie content for each crop from the Food and Agricultural Organization (FAO) (2001) as suggested by Franck et al. (2011).

\subsection{Observed CFT fractions}

15 Total observed areas for each crop were taken from the same dataset as observed yield (SPAM) (You et al., 2013). In contrast to yield, this dataset contains only the total cropland area for each crop (rather than separating between areas into different types of management). CFT fractions $\left(\omega_{c}\right)$ were calculated as the summed area of each CFT (c), divided by the total area of the 7 CFTs within each grid cell for all cells with at least 20 one CFT present. The fraction of a CFT $\left(\omega_{C}\right)$ was assumed to be zero if either $Y_{\text {current,o,c }}$ or $Y_{\text {current }, p, c}$ was close to zero $\left(<0.01 \mathrm{~kg} \mathrm{~m}^{-2}\right)$.
ESDD

5, 1571-1606, 2014

Optimizing cropland cover for stable food production in Sub-Saharan Africa

P. Bodin et al.

Title Page

Abstract Introduction

Conclusions References

Tables Figures

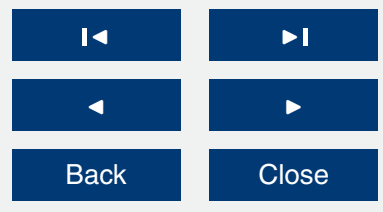

Full Screen / Esc

Printer-friendly Version

Interactive Discussion 


\subsection{Portfolio optimization}

Modern Portfolio Theory (MPT) (Markowitz, 1959) is a theory in finance which aims at selecting a portfolio of stocks to maximize the return of the portfolio whilst minimizing its variance. This concept has been transferred from risk management in finance 5 to agriculture by studying the optimum distribution of crops to maximize profit (Nalley et al., 2009) or to minimize the variance in yield (Nalley and Barkley, 2010). Focusing on feeding the maximum number of people, yield measured in calories could be maximized or its variance minimized using MPT by crop selection.

The two variables used in MPT are the mean return of the portfolio, or in the case for 10 crops in this study, the mean yield for the total cropland area in each grid cell over the selected time period $\left(Y_{\mathrm{pf}, c}\right.$ in $\left.\mathrm{kcal} \mathrm{m}^{-2}\right)$, and the variance $\left(\sigma^{2}\right.$ in $\left.\mathrm{kcal}^{2} \mathrm{~m}^{-4}\right)$ in the same yield over the same time period. $Y_{\mathrm{pf}, c}$ was calculated as the area-weighted decadal mean yield of all CFTs in each grid cell, for each optimization period:

$Y_{\mathrm{pf}}=\frac{\sum_{t=1}^{a} \sum_{c=1}^{b} \omega_{c} Y_{\mathrm{cal}, c, t}}{a}$

15 where $t$ is year number in the optimization period, $c$ is the CFT index (a number between 1-7 where each number represents one CFT), $a$ is number of years of the optimization time period, $b$ is number of CFTs, and $\omega_{c}$ is the cropland fraction of CFT $c$. Variance is the area weighted sum of the variance in crop yield calculated as:

$\sigma^{2}=\sum_{c=1}^{b} \sum_{d=1}^{b} \omega_{c} \omega_{d} \sigma_{c, d}$

20 where $c$ and $d$ are CFT indices, $b$ is the number of CFTs and $\sigma$ is the covariance in crop yield of the two CFTs $c$ and $d$ over the optimization period when $c \neq d$ and the variance of CFT $c$ (or $d$ ) when $c=d$.
ESDD

5, 1571-1606, 2014

Optimizing cropland cover for stable food production in Sub-Saharan Africa

P. Bodin et al.

Title Page

Abstract

Conclusions

Tables

Figures

14

4

Back Introduction References

$\rightarrow$ $\checkmark$ Close

Full Screen / Esc

Printer-friendly Version

Interactive Discussion 
MPT identifies two separate optimization options (see below). In our study the optimizations were made numerically by looking at all permutations of the relative distribution of the different CFTs measured as even $10 \%$ fractional cover. A simple example would be $70 \%$ TeWW, $20 \%$ TeCo and $10 \%$ TrMi. $Y_{\text {pf }}$ and $\sigma^{2}$ for all possible permutations of $10 \%$ fractional cover each $(n=6750)$ were calculated and then compared against baseline values of $Y_{\mathrm{pf}}$ and $\sigma^{2}\left(Y_{\mathrm{pf} \text {, base }}\right.$ and $\left.\sigma_{\text {base }}^{2}\right)$. These baseline values were calculated using simulated and normalized yield $\left(Y_{\text {cal }, C}\right)$ and variance $\left(\sigma^{2}\right)$ (Eqs. 3-4) for current climate (1996-2005) and by using current CFT fractions taken from the SPAM dataset. The three optimization strategies were:

1. Minimizing variance while maintaining yield $\left(\mathrm{Opt}_{\mathrm{v}, \mathrm{min}}\right)$

The optimization was made by finding the relative distributions of CFTs that gave a $Y_{\mathrm{pf}}>Y_{\mathrm{pf} \text {, base }}$ and from these finding the combination of fractions that gave the lowest variance.

2. Maximizing yield while maintaining variance $\left(\mathrm{Opt}_{\mathrm{y}, \max }\right)$

The optimization was made by finding the relative distributions of CFTs that gave a $\sigma^{2}<\sigma_{\text {base }}^{2}$ and from these finding the combination of fractions that gave the highest yield.

3. Highest-yielding single crop $\left(\mathrm{Opt}_{\mathrm{s}, \mathrm{crop}}\right)$

In addition to the two MPT optimization methods we also selected the single CFT that gave the highest average yield for each time period with no account taken to variance in yield.

The result from each optimization was a new set of optimum CFT fractions. From Opt $_{\mathrm{v}, \min }$ we also obtained an optimum (low) $\sigma^{2}$ and for Opt $\mathrm{y}_{\mathrm{y} \text { max }}$ an optimum (high) $Y_{\mathrm{pf}}$. These values were then, for each individual grid cell compared against $\sigma^{2}$ and $Y_{\mathrm{pf}}$

\section{ESDD}

$5,1571-1606,2014$

Optimizing cropland

cover for stable food production in

Sub-Saharan Africa

P. Bodin et al.

Title Page

Abstract

Conclusions

Tables

\section{Figures}

14

$\hookrightarrow$

Back

Full Screen / Esc

Printer-friendly Version

Interactive Discussion 
As the optimization is done numerically it is possible for the optimization to fail, in two different ways, even for current climate. Firstly it is possible that no crop distribution of even $10 \%$ fractions generates a $Y_{\mathrm{pf}}$ that is higher $\left(\mathrm{Opt}_{\mathrm{v}, \min }\right.$ and $\left.\mathrm{Opt}_{\mathrm{s}, \mathrm{crop}}\right)$ or a variance that is lower $\left(\mathrm{Opt}_{\mathrm{y}, \mathrm{max}}\right)$ than the baseline $\left(Y_{\mathrm{pf} \text {, base }}\right)$. For the two MPT optimizations it 5 is also possible that none of the selected combinations of relative crop distributions which fulfil the first optimization criteria generate a decrease in variance $\left(\mathrm{Opt}_{\mathrm{v}, \mathrm{min}}\right)$ or an increase in yield $\left(\mathrm{Opt}_{\mathrm{y} \text {,max }}\right)$ compared to the baseline.

Further, as simulated yield and variance can both increase or decrease in a future climate and as the optimization for future climate is made using the baseline values for 10 current climate it is possible that the optimized yield becomes lower for Opt $\mathrm{v}_{\mathrm{min}}$, and optimized variance becomes higher for $\mathrm{Opt}_{\mathrm{y}, \max }$ compared to assuming current crop distribution.

\section{Results}

\subsection{Optimized crop distribution}

15 By performing the three optimizations for current climate we generated different sets of optimal CFT distributions for each grid cell, optimization and time period. The optimized fractions for current climate compared with the observed fractions taken from the SPAM dataset are shown in Fig. 1 as the mean over all grid cells. The distributions from the two MPT optimizations were relatively similar to the observed ones, whereas for $\mathrm{Opt}_{\mathrm{s}, \mathrm{crop}}$ the distributions differed greatly, with TeCo and TrMa dominating in the simulated case (Fig. 1). In the discussion below we mainly focus on the two MPT optimizations, as $\mathrm{Opt}_{\mathrm{s}, \mathrm{crop}}$ generally can be seen as a theoretical case, especially in relation to subsistence farming.

The most striking difference between the observed fractions and the two MPT op25 timizations was found for TeSb where the optimized fractions were $\sim 10$ times larger, being calculated around 10\%, rather than 1\% (Fig. 1). For TeWW the fractions were
ESDD

$5,1571-1606,2014$

\section{Optimizing cropland cover for stable food production in Sub-Saharan Africa \\ P. Bodin et al.}

\section{Title Page}

Abstract Introduction

Conclusions References

Tables Figures

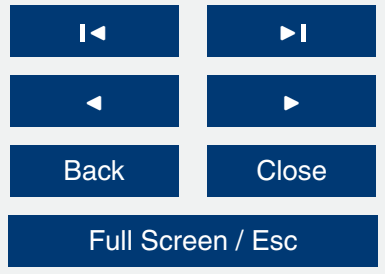

Printer-friendly Version

Interactive Discussion 
ca. 2 times larger, while the optimized TePu fractions were about two thirds to one half. The difference in crop distributions between the two individual MPT optimizations was relatively small, with $20 \%$ larger fractions of TeSb and TrMa and $20 \%$ lower fractions of TePu and TrMi for Opt $\mathrm{y}_{\text {,max }}$ Compared to Opt $\mathrm{v}_{\mathrm{v} \text { min }}$ (Fig. 1).

5 Latitudinally, the fractional cover of the three most important groups of crops in SSA (based on number of calories produced, FAOSTAT, 2013) varied strongly for both optimized (Opt $\mathrm{v}_{\mathrm{r} \text { min }}$ and Opt $\left.\mathrm{y}_{\mathrm{y} \text { max }}\right)$, and observed fractional crop cover (Fig. 2a-c). A strong positive correlation $(p<0.001)$ was found between the optimized and observed fractions for all these CFTs (Table 2). For the remaining four CFTs the correlation was 10 significant (for both Opt $\mathrm{v}_{\text {,min }}$ and $\mathrm{Opt}_{\mathrm{y}, \max }$ ) for TeWW and TePu but not for TrRi and TeSb. The largest differences between the mean observed and optimized fractions for $\mathrm{TeSb}, \mathrm{TrRi}$ and TeWW were found between 10 and $25^{\circ} \mathrm{S}$ (Fig. S1 in the Supplement). $\mathrm{TeSb}$ was the only CFT for which there was a significant correlation for Opt $\mathrm{s}_{\mathrm{s} \text { crop }}$ and not the MPT optimizations.

15 When performing the optimizations for future climate, the optimized fractional cover changed slightly compared to the optimizations made for current climate. For both MPT optimizations there were relatively large increases over time in the areas of $\operatorname{TrRi}$ (Fig. S2). For Opt ${ }_{v, \text { min }}$ there was a large increase in TrMi and a large decrease in TrMa over time whereas for Opt $\mathrm{y}_{\text {,max }}$ there was relatively large increase for TePu. These

\section{changes in CFT over time varied slightly with latitude (Figs. S3-S4). For Opt ${ }_{\text {s,crop }}$} the dominating crops were TrMa and TeSb with a small relative increase in TrMa and a small decrease in TeSb for future climate (Figs. 1 and $\mathrm{S} 2$ ).

\subsection{Spatial and temporal differences in yield and variance for Sub-Saharan Africa}

25 In the optimization analysis the baseline values of $Y_{\mathrm{pf}}$ and $\sigma^{2}\left(Y_{\mathrm{pf} \text {, base }}\right.$ and $\left.\sigma_{\text {base }}^{2}\right)$ were calculated based on both current (observed) crop distributions and current climate. For future climate it is more interesting to compare optimized $Y_{\mathrm{pf}}$ and $\sigma^{2}$ against values calculated for the same climate conditions but assuming no change in crop
ESDD

$5,1571-1606,2014$

\section{Optimizing cropland cover for stable food production in Sub-Saharan Africa \\ P. Bodin et al.}

\section{Title Page}

Abstract Introduction

Conclusions References

Tables Figures

14 4

Back

Printer-friendly Version

Interactive Discussion 
distribution from the observed ones. The optimized values of $Y_{\mathrm{pf}}$ and $\sigma^{2}$ were thus compared against the baseline values calculated based on the same (current or future) climate conditions but current observed crop distributions $\left(Y_{\mathrm{pf}, \mathrm{bcl}}\right.$ and $\left.\sigma_{\mathrm{bcl}}^{2}\right)$ meaning that $Y_{\mathrm{pf}, \mathrm{bcl}}=Y_{\mathrm{pf} \text {, base }}$ and $\sigma_{\mathrm{bcl}}^{2}=\sigma_{\mathrm{base}}^{2}$ for current climate. The grid cell median value of $Y_{\mathrm{pf}, \mathrm{bcl}}$ 5 for SSA was $380 \mathrm{kcal} \mathrm{m}^{-2}$ with a median value for $\sigma_{\mathrm{bcl}}^{2}$ of $2100 \mathrm{kcal}^{2} \mathrm{~m}^{-4}$ for current climate (Fig. 3). We chose median rather than mean, as for some grid cells the variance displayed extreme values ( $>1000$ times larger than the median) which would have distorted the mean. Reflecting simulated yield increases in the future, a result mostly in response to enhanced atmospheric $\mathrm{CO}_{2}$ levels (Rosenzweig et al., 2013), there was an increase in $Y_{\mathrm{pf} \text {, bcl }}$ over time (Fig. 3a). For the majority of the grid cells ( $\sim 65 \%$ ), the increase in $Y_{\text {pf, bcl }}$ was also accompanied by an increase in $\sigma_{\mathrm{bcl}}^{2}$ leading to an increase in grid cell median $\sigma_{\mathrm{bcl}}^{2}$ over time (Fig. 3b). Following the definition of the two MPT optimization strategies, Opt $\mathrm{v}_{\text {,min }}$ generated a grid cell median value of $Y_{\mathrm{pf}}$ and $\mathrm{Opt}_{\mathrm{y}, \max }$ a median value of $\sigma^{2}$ close to their respective baseline values $\left(Y_{\text {pf, base }}\right.$ and $\left.\sigma_{\text {base }}^{2}\right)$ for 15 both future and current climate (Fig. 3). For Opt $\mathrm{s}_{\mathrm{s}, \mathrm{crop}}$ both $Y_{\mathrm{pf}}$ and $\sigma^{2}$ were much larger than $Y_{\mathrm{pf}, \mathrm{bcl}}$, and $\sigma_{\mathrm{bcl}}^{2}$ for current climate (100 and $440 \%$ larger respectively), and both $Y_{\text {pf }}$ and $\sigma^{2}$ increased notably over time (Fig. $3 a$ and b). The results from comparing the difference between the optimized values of $Y_{\mathrm{pf}}$ and $\sigma^{2}$ and the values of $Y_{\mathrm{pf}, \mathrm{bcl}}$, and $\sigma_{\mathrm{bcl}}^{2}$ for current and future climates are presented below:

\subsubsection{Minimizing variance while maintaining yield $\left(0 p t_{v, \min }\right)$}

For current climate conditions, the set of assumptions that underlie optimization approach $O \mathrm{pt}_{\mathrm{v}, \mathrm{min}}$ resulted in $\sigma^{2}$ being lower than $\sigma_{\mathrm{bcl}}^{2}$ with the grid cell median value of $\sigma^{2}$ being $30 \%$ lower than $\sigma_{\mathrm{bcl}}^{2}$ (Fig. $3 \mathrm{~b}$ ). This relative difference between $\sigma^{2}$ and $\sigma_{\mathrm{bcl}}^{2}$ varied slightly spatially with large potential to decrease variance regionally (e.g. Central
ESDD

$5,1571-1606,2014$

Optimizing cropland cover for stable food production in Sub-Saharan Africa

P. Bodin et al.

\section{Title Page}

Abstract

Conclusions

Tables

References Figures

14

4

Back

Printer-friendly Version

Interactive Discussion 
African Republic, Democratic Republic of Congo and Zambia) (Fig. 4a). For $35 \%$ of the grid cell this potential to decrease variance was $>25 \%$ (Table 3 ).

ESDD

As a consequence of yield-increases over time being larger than the increase in variance (assuming current crop distribution), the potential of decreasing $\sigma^{2}$ by crop 5 selection became larger for future climate, mainly in central and western Africa (Fig. 4b and c). For the two future time periods, a total of $\sim 75-80 \%$ of the grid cells displayed a potential to decrease $\sigma^{2}$ by $>25 \%$ compared to assuming current crop distributions $\left(\sigma_{\mathrm{bcl}}^{2}\right)$ (Table 3).

For current climate, there existed at least one set of crop fractions that fulfilled the 10 first optimization criteria $\left(Y_{\mathrm{pf}}>Y_{\mathrm{pf}}\right.$, base $)$. For some grid cells $(\sim 15 \%)$ none of the crop distributions that fulfilled the first optimization criterion displayed a lower variance than the baseline, meaning that optimization failed. These grid cells were mainly located in central and south western SSA. The number of grid cells for which the difference between optimized $\sigma_{\mathrm{bcl}}^{2}$ and variance assuming current crop distribution $\left(\sigma_{\mathrm{bcl}}^{2}\right)$ was > $1525 \%$ was low $(<1 \%$ ) (Table 3$)$.

Whilst optimization of crop area following Opt $\mathrm{v}_{\mathrm{r} \text { min }}$ was successful at reducing yield variance, and this reduction was increased under future climate, this optimization foregoes increases in yield that are projected to occur under current crop distribution (Fig. 3a). In other words, further reductions in variance are traded off against yield increases. This loss of future yield potential was largest in parts of the south western and of northeastern SSA (Fig. S5b and c). For the time period 2056-2065, yield for optimized crop distribution was $>25 \%$ lower compared to current crop distribution for $\sim 10 \%$ of the grid cells and for the time period $2081-2090$ this figure was $~ 35 \%$ (Table 3).

\subsubsection{Maximizing yield while maintaining variance $\left(\mathrm{Opt}_{\mathrm{y}, \max }\right)$}

For current climate, the set of assumptions made in optimization approach Opt $_{\mathrm{y} \text { max }}$ meant that the grid cell median value of $Y_{\mathrm{pf}}$ was larger than $Y_{\mathrm{pf}}$, base with the grid cell median value being $\sim 15 \%$ larger than the baseline. The potential to increase yield

\section{Optimizing cropland cover for stable food production in Sub-Saharan Africa \\ P. Bodin et al.}

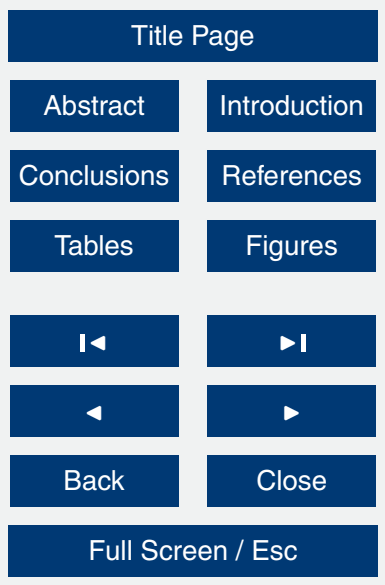

Printer-friendly Version

Interactive Discussion 
was largest in southern SSA, and regionally in western and northeaster SSA (e.g. in the Democratic Republic of Congo and Kenya) (Fig. 5a). In total $\sim 15 \%$ of the grid cells displayed the potential to increase yield by $>25 \%$ compared to using current crop distributions $\left(Y_{\mathrm{pf}, \mathrm{bcl}}\right)$ (Table 3).

Both the grid cell median optimized $Y_{\mathrm{pf}}$ and $Y_{\mathrm{pf} \text {, bcl }}$ increased slightly over time (Fig. 3a). The difference between optimized $Y_{\mathrm{pf}}$ and $Y_{\mathrm{pf} \text {, bcl }}$ varied spatially and the largest potential to increase yield compared to assuming current crop distributions was found in western, southern and northeaster SSA as well as the Sahel (Fig. 5b and c).

Along similar lines as for Opt $\mathrm{v}_{\mathrm{v} \text { min }}$ there existed at least one set of crop fractions 10 that fulfilled the first optimization criteria $\left(\sigma^{2}<\sigma_{\mathrm{bcl}}^{2}\right)$. For $\sim 10 \%$ of the grid cells the optimized $Y_{\mathrm{pf}}$ however was lower than $Y_{\mathrm{pf} \text {, bcl. }}$. For none of these grid cells the difference was $>25 \%$ (Table 3 ).

The optimized $\sigma^{2}$ for future climate were in many cases lower than $\sigma_{\mathrm{bcl}}^{2}$, largely because the optimization for variance was made against $\sigma_{\text {base }}^{2}$ (current climate) and as 15 grid cell median $\sigma_{\text {base }}^{2}$ increased over time (Fig. 3b). For $\sim 40 \%$ of the grid cells, this potential to decrease variance was $>25 \%$ (Table 3 ). In cases where $\sigma_{\mathrm{bcl}}^{2}$ decreased over time the difference instead became positive and for $\sim 20-25 \%$ of the grid cells the relative difference between $\sigma^{2}$ and $\sigma_{\text {base }}^{2}$ was $>25 \%$. The largest potential of decreasing $\sigma^{2}$ was found for central and western parts of SSA, while the largest increase in variance occurred in southern and northeaster SSA; as well as the Sahel (Fig. S6b and $\mathrm{c}$ ).

From the results above (Table 3) it can be seen that in case of Opt ${ }_{y, \max }$, it was potentially possible to simultaneously increase yield and to decrease variance by $25 \%$ for future climate compared to assuming current crop distribution for a number of grid cells. The number of grid cells for which both these criteria were met was $\sim 5 \%$. By contrast, if looking at the possibility to increase yield by $10 \%$ instead, whilst decreasing variance by the same magnitude, the number of grid cells for which this occurred was $\sim 10 \%$ for Opt $_{\mathrm{y}, \max }$. The grid cells for which it is possible to increase yield while at the
ESDD

$5,1571-1606,2014$

Optimizing cropland cover for stable food production in Sub-Saharan Africa

P. Bodin et al.

Title Page

Abstract Introduction

Conclusions References

Tables

Figures

14

4

Back

Full Screen / Esc

Printer-friendly Version

Interactive Discussion 
same time decreasing the yield variance are mainly located in western SSA, Angola and Tanzania (Fig. S7).

\section{Discussion}

The observed mean distributions of crops in SSA seem to follow the crop distributions 5 from the two MPT optimizations for most crops relatively well (Figs. 1-2, Figs. S1-S2) suggesting that farmers or farming systems in SSA indeed are following some risk aversion/yield maximization strategy. The significant correlation between the current latitudinal distribution of all crops (except TeSb and TrRi) and the MPT optimized distribution further supports this. In addition the relatively large number of optimization fail10 ures (15\% for Opt $\mathrm{v}_{\mathrm{v} \text { min }}$ and $10 \%$ for Opt $\mathrm{y,max}$ ), indicates that current crop distributions are relatively close to the optimum ones regionally (yellow to red colours in Figs. $4 a$ and $5 \mathrm{a}$ ).

The agreement is best for the dominating crops in SSA whereas the poorer agreement was found for the less important crops such as TrRi, TePu and TeSb. This sug15 gests that MPT is a good method for interpreting the present-day general crop patterns of major crops across SSA. The study was done for SSA, a region where subsistence farming is dominating. For agricultural regions in other continents or agricultural regions outside SSA additional drivers likely affect crop selection to a much larger degree. Examples of such drivers could be the maximization of profit (rather than the 20 number of calories), or regional to local policies (e.g. EU subsidies). Therefore, the difference found between optimized and observed crop fractional distribution for the southern parts of SSA might be explained by the dominance of commercial agriculture in these regions with the goal to rather maximize profit than the number of calories. In South Africa, which covers most of the land area south of $25^{\circ} \mathrm{S}$, commercial agriculture covers $86 \%$ of total cropland (Anon., 2012). With wheat being a major cash crop, the difference between optimized and observed fractions for TeWW in these regions is not
ESDD

$5,1571-1606,2014$

Optimizing cropland cover for stable food production in Sub-Saharan Africa

P. Bodin et al.

\section{Title Page}

Abstract Introduction

Conclusions References

Tables Figures

14 4

Back

Printer-friendly Version

Interactive Discussion 
surprising, and the underlying assumptions of the MPT (based on optimizing the total amount of calories) may not work for these regions

Along similar lines, the optimization was made under the assumption that all crops where rained, whereas in reality in some regions a substantial percentage is irrigated 5 (e.g. Balasubramanian et al., 2007) which can explain part of disagreement between present-day optimized and observed crop fractions. In particular, the underestimation in optimized fractions of rice for the region between 17 and $25^{\circ} \mathrm{S}$ could be explained by the large area of irrigated rice that can be found in Madagascar (Balasubramanian et al., 2007). Furthermore, the CFTs in LPJ-GUESS are not affected by pests, such that 10 yields respond to climatic, but not biotic stresses. This might play a role particularly for potatoes (TeSb) for which a large amount of pesticides is required compared to other crops in order to protect against, for example, late blight, a fungus responsible for large yield losses in unsprayed fields (Sengooba and Hakiza, 1999) with reported yield losses in central Africa of more than $50 \%$ (Oerke, 2006).

15 Regardless of processes such as irrigation or pests, both temperature and precipitation vary notably with latitude (Fig. 2 d) such that the large latitudinal difference in the observed fractions of the different crops, including the most important ones for Africa (Fig. $2 a-c$ ), could be explained well by climate variability (Table 2). The latitudinal mean fractions of the different CFTs for the two MPT optimizations could in most cases be explained by the same climate variables (Table 2). The exceptions were TeCo and TeSb where neither of the MPT optimized latitudinal distribution showed any correlation with temperature $(\mathrm{TeCo})$ or precipitation $(\mathrm{TeSb})$. For Opt $\mathrm{v}_{\mathrm{v} \text { min }}$ there was also no correlation between the optimized fractions of TeSb and temperature.

The strong correlation between observed fractions of both TrMi (positive) and TeWW 25 (negative); and temperature and between TrMa and precipitation could be explained by their respective optimum ranges for temperature and precipitation. Millet has a high optimum temperature for growth $\left(25-35^{\circ} \mathrm{C}\right)$ whereas wheat has a low optimum temperature $\left(15-23^{\circ} \mathrm{C}\right)$; and cassava a very high optimum precipitation (1000$1500 \mathrm{~mm}$ ) (Ecocrop, 2014). For TeCo, the negative correlation with temperature likely
ESDD

$5,1571-1606,2014$

\section{Optimizing cropland cover for stable food production in Sub-Saharan Africa}

P. Bodin et al.

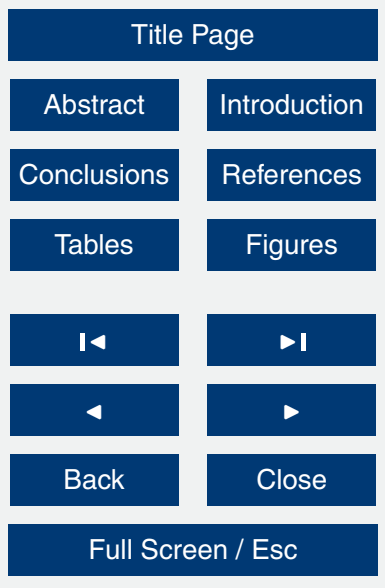

Printer-friendly Version

Interactive Discussion 
is dominated by the northernmost and southernmost latitudes of SSA where temperatures are near the high (north) and low (south) end of optimum climate for maize (18$\left.33^{\circ} \mathrm{C}\right)$ (Ecocrop, 2014). The large difference between optimized and observed fractions of $\mathrm{TeWW}, \mathrm{TeSb}$ and $\mathrm{TePu}$ between 10 and $25^{\circ} \mathrm{S}$ in our study indicate that the global 5 model parameterization for these crops might not be ideal for the climatic conditions in these regions.

Given the high correlation between observed and optimized crop distributions for current climate the distributions for future climate could be seen as scenarios of changes in crop distributions in regions where agriculture is focused on local sustenance. These 10 types of scenarios could be alternatives to assuming no change in land use and crop distribution as is frequently done in impact studies that focus on changes in yields (Rosenzweig et al., 2014; Schlenker and Lobell, 2010; Liu et al., 2008; Müller et al., 2010). Earlier studies looking at trends in crop selection have mostly done so from the perspective of societal demand for various crops (Wu et al., 2007). Our study in15 stead focus on the supply side but taking into account also aspects of food production stability, thus offering a complement to these types of studies.

For $\mathrm{Opt}_{\mathrm{s}, \mathrm{crop}}$ we identified the single highest yielding crop for current future climate. As simulated yield was normalized against observed yield this selection mainly represents differences in yield from the SPAM dataset (You et al., 2013). The study by Franck et al. (2011) instead found the highest simulated yield (using LPJmL) for TeSb (in their study named sugar beet) followed by TeCo (maize). The reason for these differences is likely mainly caused by the fact that they assumed intensive agricultural practices for all crops in order to compute maximum (potential) yield and did not normalize against observed (actual) yield.

In our study we investigated the ability to increase yield for a portfolio of crops while keeping variance constant at current levels or vice versa. At the local scale, MPT has been applied for the selection of crop varieties (Nalley and Barkley, 2010; Nalley et al., 2009). For a range of experimental sites in Arkansas, USA, the results from these earlier studies indicate the potential to decrease variance in rice yield by up to $70 \%$
ESDD

5, 1571-1606, 2014

\section{Optimizing cropland cover for stable food production in Sub-Saharan Africa}

P. Bodin et al.

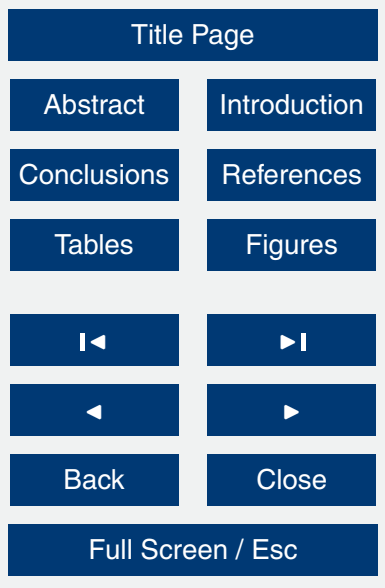

Printer-friendly Version

Interactive Discussion 
through the selection of different rice varieties while keeping yield constant $\left(\mathrm{Opt}_{\mathrm{v}, \mathrm{min}}\right)$, or to increase profit by up to $23 \%$ while keeping variance in yield constant $\left(\mathrm{Opt}_{\mathrm{y}, \mathrm{max}}\right)$ (Nalley et al., 2009). Using the same approach, it was also possible to decrease calculated variance in wheat yield in north western Mexico by up to $33 \%$ (Nalley and 5 Barkley, 2010). The median ability to reduce variance or to increase yield in our study was of the same order of magnitude, but with large spatial variability (Figs. 4-5).

Other studies have found a large potential to increase food production by selecting the single highest yielding crop (Opt s,crop ) (Koh et al., 2013; Franck et al., 2011). In the study by Koh et al. (2013) the highest yielding cereal (in tha ${ }^{-1}$ ) (choosing between bar10 ley, maize, millet, rice, sorghum and wheat) for each 5 min grid cell was selected using data from Monfreda et al. (2008). Their results gave an increase in yield by $68 \%$ in eastern Africa and $87 \%$ in central Africa when selecting the highest yielding crop compared to current crop distribution. These results are lower than the increase in yield found from selecting the highest yielding crop in our study $\left(\mathrm{Opt}_{\mathrm{s}, \mathrm{crop}}\right)$. Their study how15 ever was confined to cereals and did not take into account any difference in dry weight and calorie content of the different crops. As can be seen from our results, selecting the highest yielding crop generates not only a large increase in yield compared to current crop distribution but also an even larger increase in yield variance. Therefore this option is not a realistic one in most cases and should be seen as a theoretical rather 20 than practical option.

Model impact studies have traditionally focused on changes in mean yield, ignoring the effect on variance. Some earlier studies exist on changes in future variance in yield (Urban et al., 2012; Chavas et al., 2009), but these studies looked at the effect of climate change on yield variability of single crops and not as was done in our study of 25 a portfolio of crops.

Another option for increasing food production that has been discussed extensively is the closing of the so-called yield gap (Licker et al., 2010; Foley et al., 2011). Over large parts of SSA, there is a potential of increasing yields of many existing crops by a factor of $\sim 10$ through agricultural intensification (Licker et al., 2010). There are however large
ESDD

$5,1571-1606,2014$

\section{Optimizing cropland cover for stable food production in Sub-Saharan Africa}

P. Bodin et al.

\section{Title Page}

Abstract

Conclusions

Tables

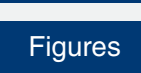

14

4

Back

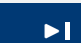

$\Delta$

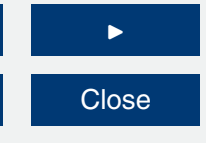

Full Screen / Esc

Printer-friendly Version

Interactive Discussion 
obstacles for increasing yields due to, for example, high costs of fertilizers and lack of surface water for irrigation. Reducing the yield gap in SSA to a difference of $75 \%$ between actual and potential yield in general requires both increasing nutrient application and irrigated areas (Mueller et al., 2012). Switching from one mix of crops to another, 5 maximizing yield while keeping an acceptable level of variance, as suggested by this study might prove to be a cost-effective and food secure measure to produce more calories.

AgroDGVM models, like the LPJ-GUESS model used in this study, have the advantage of being able to simulate changes in yield and variance over large regions and for 10 long time periods. This advantage comes at the price of lack in spatial detail and several generalizations have to be made (related to e.g. soil types, local climate and crop management, and the effect of heat stress) (Rosenzweig et al., 2014; Bondeau et al., 2007). In addition, there are uncertainties related to model input. There may be biases in the climate input data generating possible errors, particularly in the variance of simu15 lated yield. Our analysis was made using bias corrected climate data from 5 GCMs and the median results from these model runs were used. Simulated fluxes of carbon using LPJ-GUESS have been shown to be highly sensitive to the choice of GCM (Ahlström et al., 2012). Averaging over several GCMs smooths some of the spatial and temporal variability from the individual GCMs, which will affect the calculated variance. To get realistic values of simulated yield these were normalized against yield from the SPAM database. Variance in yield was however not normalized against measured data as the availability of realistic data for evaluating interannual variability in yield is limited. One potentially useful dataset is the one created by lizumi et al. (2014) where reported data of harvested area for the year 2000, country yield statistics and satellite-derived net primary production were combined to generate a spatiotemporal gridded dataset of yield for a range of crops. However, two issues prevent comparison of simulated yield against this dataset, grid by grid. Firstly the dataset shows clear differences in interannual variability between grid cells on opposite sides of political borders, meaning that yield dynamics to a great extent contain artefacts likely generated by, for example
ESDD

5, 1571-1606, 2014

\section{Optimizing cropland cover for stable food production in Sub-Saharan Africa}

P. Bodin et al.

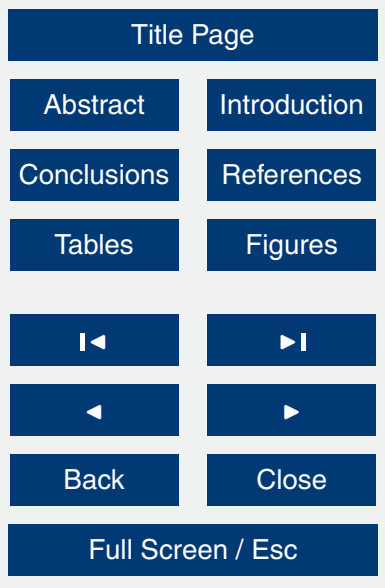

Printer-friendly Version

Interactive Discussion 
differences in the reporting of national yields. Secondly, the climate input data used in this study was based on GCM model runs which albeit having been bias corrected cannot be said to represent the actual climate variability for each individual grid cell even for current climate. Earlier validation tests for Africa have however shown the ability of 5 LPJ-GUESS to reproduce interannual variability in maize yield at the country level as reported by the FAO (Lindeskog et al., 2013).

This study investigated one aspect of food security, that is, the generation of a large and/or stable number of calories from existing cropland. From a food security perspective many other factors are equally important, such as access to markets and the

10 nutritional quality and safety of food. For example, not getting enough calories is only one part of food safety problem. In addition to not getting enough calories, micronutrient deficiency is a large problem with an estimated 2 billion people being affected (Tulchinsky, 2010). Also, at the same time as many people still suffer from malnutrition, obesity is a growing problem in the developing world (Godfray and Garnett, 2014; 15 Steyn and Mchiza, 2014) meaning that people simultaneously can be both undernourished and obese. This study focused on staple crops but for a fully nutritional diet these foods need to be complemented by foods which may be richer in minerals, vitamins and proteins (DeClerck et al., 2011).

\section{Conclusions}

20 The results from this study are based on the optimization of yield and variance for groups of crops in SSA keeping yield or variance constant based on observed values for the current situation. This represents the trade-off between high yield and stable food production. The results show a potential to increase current or future yield and/or yield stability of a portfolio of crops by applying Modern Portfolio Theory to simulated 25 crop yield.

It can be seen from our analysis that the spatial distribution of most crops follow that from observations, meaning that today's farming systems to a great extent seem to
ESDD

$5,1571-1606,2014$

\section{Optimizing cropland cover for stable food production in Sub-Saharan Africa \\ P. Bodin et al.}

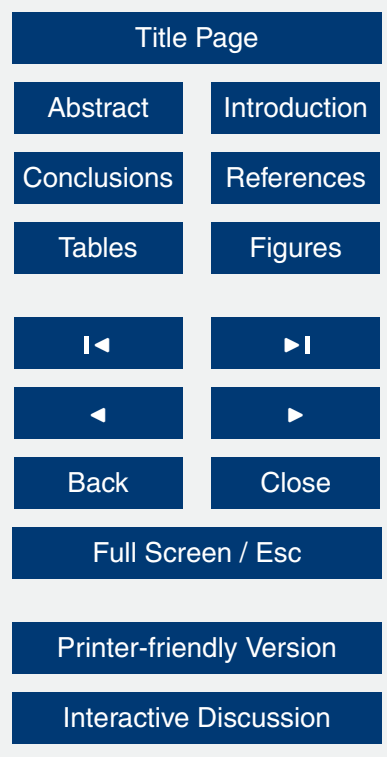


follow the optimization rules of Modern Portfolio Theory for crop selection. Because of these similarities we suggest that our approach can be used to generate future scenarios of sown areas for crops in SSA and likely similar regions, where food security is highly dependent on local food production. We also clearly demonstrate that selecting 5 the highest yielding crop is not a valid option in regions such as SSA, as doing this would generate unacceptably high variance in food production.

Our study highlights the great potential of Modern Portfolio Theory for answering questions about crop selection under current and future climate and its effect on yield and yield variability. It is possible to add further constraints to the optimization, for 10 example by excluding crop distributions from the analysis that generate complete (or near complete) crop failures for any one year. Depending on the scale of the study other aspects related to agriculture could be taken into account in the optimization, for example carbon storage in the soil, pesticide/fertilizer use and the nutritional value of various crops.

15 The Supplement related to this article is available online at doi:10.5194/esdd-5-1571-2014-supplement.

Acknowledgements. This work was supported by the ClimAfrica project funded by the European Commission under the 7th Framework Program (FP7), grant number 244240 (http: //www.climafrica.net/). A. Arneth and T. A. M. Pugh also acknowledge support from the 7th

20 Framework Program LUC4C (grant no. 603542). S. Olin was funded by the FORMAS Strong Research Environment: land use today and tomorrow.
ESDD

$5,1571-1606,2014$

Optimizing cropland cover for stable food production in Sub-Saharan Africa

P. Bodin et al.

Title Page

Abstract Introduction

Conclusions References

Tables Figures

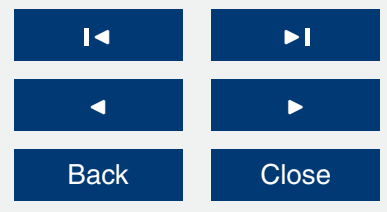

Full Screen / Esc

Printer-friendly Version

Interactive Discussion 


\section{References}

Ahlström, A., Schurgers, G., Arneth, A., and Smith, B.: Robustness and uncertainty in terrestrial ecosystem carbon response to CMIP5 climate change projections, Environ. Res. Lett., 7, 044008, doi:10.1088/1748-9326/7/4/044008, 2012.

5 Anon.: Abstract of Agricultural Statistics, Department of Agriculture, Forestry and Fisheries, Pretoria, South Africa, 2012.

Balasubramanian, V., Sie, M., Hijmans, R., and Otsuka, K.: Increasing rice production in SubSaharan Africa: challenges and opportunities, Adv. Agron., 94, 55-133, 2007.

Barrios, S., Ouattara, B., and Strobl, E.: The impact of climatic change on agricultural production: is it different for Africa?, Food Policy, 33, 287-298, 2008.

Berg, A., Sultan, B., and Noblet-Ducoudré, N.: Including tropical croplands in a terrestrial biosphere model: application to West Africa, Climatic Change, 104, 755-782, doi:10.1007/s10584-010-9874-x, 2011.

Bondeau, A., Smith, P. C., Zaehle, S., Schaphoff, S., Lucht, W., Cramer, W., Gerten, D., LoetzeCampen, H., Müller, C., and Reichstein, M.: Modelling the role of agriculture for the 20th century global terrestrial carbon balance, Global Change Biol., 13, 679-706, 2007.

Chavas, D. R., Izaurralde, R. C., Thomson, A. M., and Gao, X.: Long-term climate change impacts on agricultural productivity in eastern China, Agr. Forest Meteorol., 149, 1118-1128, 2009.

DeClerck, F. A., Fanzo, J., Palm, C., and Remans, R.: Ecological approaches to human nutrition, Food Nutr. Bull., 32, 41S-50S, 2011.

Deryng, D., Sacks, W. J., Barford, C. C., and Ramankutty, N.: Simulating the effects of climate and agricultural management practices on global crop yield, Global Biogeochem. Cy., 25, GB2006, doi:10.1029/2009gb003765, 2011.

25 Di Vittorio, A. V., Anderson, R. S., White, J. D., Miller, N. L., and Running, S. W.: Development and optimization of an Agro-BGC ecosystem model for C4 perennial grasses, Ecol. Model., 221, 2038-2053, doi:10.1016/j.ecolmodel.2010.05.013, 2010.

Ecocrop: available at: http://ecocrop.fao.org/, last access: 7 October 2014.

FAOSTAT: available at: http://faostat.fao.org/ (last access: 2 October 2014), 2013.
ESDD

5, 1571-1606, 2014

Optimizing cropland

cover for stable food production in

Sub-Saharan Africa

P. Bodin et al.

\section{Title Page}

Abstract

Introduction

Conclusions References

Tables

Figures

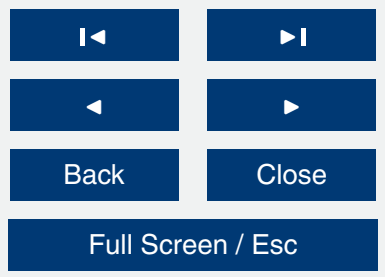

Printer-friendly Version

Interactive Discussion 
Fischer, G., Nachtergaele, F., Prieler, S., Teixeira, E., Tóth, G., van Velthuizen, H., Verelst, L., and Wiberg, D.: Global Agro-Ecological Zones (GAEZ v3.0): model documentation, International Institute for Applied Systems Analysis (IIASA), Laxenburg, Austria and the Food and Agriculture Organization of the United Nations (FAO), Rome, Italy, 2012.

5 Foley, J. A., Ramankutty, N., Brauman, K. A., Cassidy, E. S., Gerber, J. S., Johnston, M., Mueller, N. D., O'Connell, C., Ray, D. K., and West, P. C.: Solutions for a cultivated planet, Nature, 478, 337-342, 2011.

Food and Agricultural Organisation: Food Balance Sheets, A Handbook, Rome, 2001.

Food and Agricultural Organisation: The State of Food Insecurity in the World 2013: The Multiple Dimensions of Food Security, Rome, 2013.

Franck, S., von Bloh, W., Müller, C., Bondeau, A., and Sakschewski, B.: Harvesting the sun: new estimations of the maximum population of planet Earth, Ecol. Model., 222, 2019-2026, doi:10.1016/j.ecolmodel.2011.03.030, 2011.

Gervois, S., de Noblet-Ducoudré, N., Viovy, N., Ciais, P., Brisson, N., Seguin, B., and Perrier, A.: 15 Including croplands in a global biosphere model: methodology and evaluation at specific sites, Earth Interact., 8, 1-25, 2004.

Godfray, H. C. J. and Garnett, T.: Food security and sustainable intensification, Philos. T. Roy. Soc. B, 369, 1-10, doi:10.1098/rstb.2012.0273, 2014.

Hickler, T., Smith, B., Sykes, M. T., Davis, M. B., Sugita, S., and Walker, K.: Using a generalized vegetation model to simulate vegetation dynamics in northeastern USA, Ecology, 85, 519530, 2004.

Hickler, T., Smith, B., Prentice, I. C., Mjöfors, K., Miller, P., Arneth, A., and Sykes, M. T.: $\mathrm{CO}_{2}$ fertilization in temperate FACE experiments not representative of boreal and tropical forests, Global Change Biol., 14, 1531-1542, 2008.

lizumi, T., Yokozawa, M., Sakurai, G., Travasso, M. I., Romanenkov, V., Oettli, P., Newby, T., Ishigooka, Y., and Furuya, J.: Historical changes in global yields: major cereal and legume crops from 1982 to 2006, Global Ecol. Biogeogr., 23, 346-357, 2014.

Jarvis, A., Ramirez-Villegas, J., Herrera Campo, B. V., and Navarro-Racines, C.: Is cassava the answer to African climate change adaptation?, Trop. Plant Biol., 5, 9-29, 2012.

so Knox, J., Hess, T., Daccache, A., and Wheeler, T.: Climate change impacts on crop productivity in Africa and South Asia, Environ. Res. Lett., 7, 034032, doi:10.1088/1748-9326/7/3/034032, 2012.
ESDD

5, 1571-1606, 2014

Optimizing cropland

cover for stable food production in

Sub-Saharan Africa

P. Bodin et al.

Title Page

Abstract

Conclusions

Tables

Figures

14

$\hookrightarrow$

Back

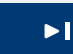

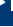

$\bullet$

Close

Full Screen / Esc

Printer-friendly Version

Interactive Discussion 
Koh, L. P., Koellner, T., and Ghazoul, J.: Transformative optimisation of agricultural land use to meet future food demands, PeerJ, 1, e188, 2013.

Licker, R., Johnston, M., Foley, J. A., Barford, C., Kucharik, C. J., Monfreda, C., and Ramankutty, N.: Mind the gap: how do climate and agricultural management explain the "yield 5 gap" of croplands around the world?, Global Ecol. Biogeogr., 19, 769-782, 2010.

Lindeskog, M., Arneth, A., Bondeau, A., Waha, K., Seaquist, J., Olin, S., and Smith, B.: Implications of accounting for land use in simulations of ecosystem carbon cycling in Africa, Earth Syst. Dynam., 4, 385-407, doi:10.5194/esd-4-385-2013, 2013.

Liu, J., Fritz, S., Van Wesenbeeck, C., Fuchs, M., You, L., Obersteiner, M., and Yang, H.: A spatially explicit assessment of current and future hotspots of hunger in Sub-Saharan Africa in the context of global change, Global Planet. Change, 64, 222-235, 2008.

Lokupitiya, E., Denning, S., Paustian, K., Baker, I., Schaefer, K., Verma, S., Meyers, T., Bernacchi, C. J., Suyker, A., and Fischer, M.: Incorporation of crop phenology in Simple Biosphere Model (SiBcrop) to improve land-atmosphere carbon exchanges from croplands, Biogeosciences, 6, 969-986, doi:10.5194/bg-6-969-2009, 2009.

Markowitz, H.: Portfolio Selection: Efficient Diversification of Investments, 16, Yale University Press, Yale, 1959.

Matthews, R. B., Rivington, M., Muhammed, S., Newton, A. C., and Hallett, P. D.: Adapting crops and cropping systems to future climates to ensure food security: the role of crop modelling,

20 Global Food Secur., 2, 24-28, 2013.

Meinshausen, M., Smith, S. J., Calvin, K., Daniel, J. S., Kainuma, M., Lamarque, J., Matsumoto, K., Montzka, S., Raper, S., and Riahi, K.: The RCP greenhouse gas concentrations and their extensions from 1765 to 2300, Climatic Change, 109, 213-241, 2011.

Monfreda, C., Ramankutty, N., and Foley, J. A.: Farming the planet: 2. geographic distribution of crop areas, yields, physiological types, and net primary production in the year 2000 , Global Biogeochem. Cy., 22, GB1022, doi:10.1029/2007GB002947, 2008.

Morales, P., Sykes, M. T., Prentice, I. C., Smith, P., Smith, B., Bugmann, H., Zierl, B., Friedlingstein, P., Viovy, N., and Sabate, S.: Comparing and evaluating process-based ecosystem model predictions of carbon and water fluxes in major European forest biomes, Global $30 \quad$ Change Biol., 11, 2211-2233, 2005.

Mueller, N. D., Gerber, J. S., Johnston, M., Ray, D. K., Ramankutty, N., and Foley, J. A.: Closing yield gaps through nutrient and water management, Nature, 490, 254-257, 2012.

\section{ESDD}

5, 1571-1606, 2014

\section{Optimizing cropland \\ cover for stable food production in \\ Sub-Saharan Africa}

P. Bodin et al.

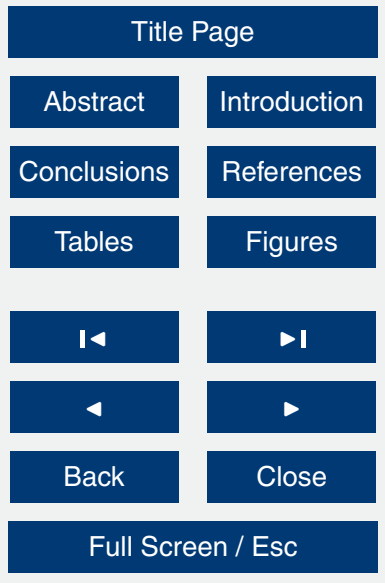

Printer-friendly Version

Interactive Discussion 
Müller, C.: Climate Change Impact on Sub-Saharan Africa: an Overview and Analysis of Scenarios and Models, German Development Institute/Deutsches Institut für Entwicklungspolitik (DIE), Bonn, 2009.

Müller, C., Bondeau, A., Popp, A., Waha, K., and Fader, M.: Climate change impacts on agricultural yields, World Bank, Washington, D.C., 2010.

Nalley, L. L. and Barkley, A. P.: Using portfolio theory to enhance wheat yield stability in lowincome nations: an application in the Yaqui Valley of Northwestern Mexico, J. Agr. Resour. Econ., 35, 334-347, 2010.

Nalley, L. L., Barkley, A., Watkins, B., and Hignight, J.: Enhancing farm profitability through portfolio analysis: the case of spatial rice variety selection, J. Agr. Appl. Econ., 41, 641-652, 2009.

Oerke, E.-C.: Crop losses to pests, J. Agr. Sci., 144, 31-43, 2006.

Rockström, J., Folke, C., Gordon, L., Hatibu, N., Jewitt, G., Penning de Vries, F., Rwehumbiza, F., Sally, H., Savenije, H., and Schulze, R.: A watershed approach to upgrade rainfed agriculture in water scarce regions through water system innovations: an integrated research initiative on water for food and rural livelihoods in balance with ecosystem functions, Phys. Chem. Earth, 29, 1109-1118, 2004.

Rosenzweig, C., Jones, J., Hatfield, J., Ruane, A., Boote, K., Thorburn, P., Antle, J., Nelson, G., Porter, C., Janssen, S., Asseng, S., Basso, B., Ewert, F., Wallach, D., Baigorrial, G., and Winter, J. M.: The agricultural model intercomparison and improvement project (AgMIP): protocols and pilot studies, Agr. Forest Meteorol., 170, 166-182, 2013.

Rosenzweig, C., Elliott, J., Deryng, D., Ruane, A. C., Müller, C., Arneth, A., Boote, K. J., Folberth, C., Glotter, M., Khabarov, N., Neumann, K., Piontek, F., Pugh, T. A. M., Schmid, E., Stehfest, E., Yang, H., and Jones, J. W.: Assessing agricultural risks of climate change in the 21st century in a global gridded crop model intercomparison, P. Natl. Acad. Sci. USA, 111, 3268-3273, doi:10.1073/pnas.1222463110, 2014.

Schlenker, W. and Lobell, D. B.: Robust negative impacts of climate change on African agriculture, Environ. Res. Lett., 5, 014010, doi:10.1088/1748-9326/5/1/014010, 2010.

Sengooba, T. and Hakiza, J.: The current status of late blight caused by Phytophthora infes30 tans in Africa, with emphasis on eastern and southern Africa, in: Proceedings of the Global Initiative on late Blight (GILB) Conference, Quito, Ecuador, 25-28, 1999.
ESDD

$5,1571-1606,2014$

\section{Optimizing cropland cover for stable food production in Sub-Saharan Africa}

P. Bodin et al.

\section{Title Page}

Abstract Introduction

Conclusions References

Tables Figures

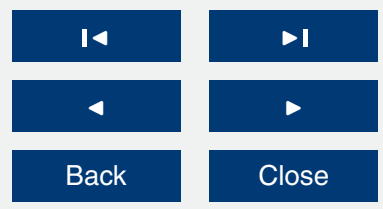

Full Screen / Esc

Printer-friendly Version

Interactive Discussion 
Sitch, S., Smith, B., Prentice, I. C., Arneth, A., Bondeau, A., Cramer, W., Kaplan, J. O., Levis, S., Lucht, W., Sykes, M. T., Thonicke, K., and Venevsky, S.: Evaluation of ecosystem dynamics, plant geography and terrestrial carbon cycling in the LPJ dynamic global vegetation model, Global Change Biol., 9, 161-185, 2003.

5 Smith, B., Prentice, I. C., and Sykes, M. T.: Representation of vegetation dynamics in the modelling of terrestrial ecosystems: comparing two contrasting approaches within European climate space, Global Ecol. Biogeogr., 10, 621-637, 2001.

Steyn, N. P. and Mchiza, Z. J.: Obesity and the nutrition transition in Sub-Saharan Africa, Ann. NY Acad. Sci., 1311, 88-101, 2014.

10 Sus, O., Williams, M., Bernhofer, C., Béziat, P., Buchmann, N., Ceschia, E., Doherty, R., Eugster, W., Grünwald, T., Kutsch, W., Smith, P., and Wattenbach, M.: A linked carbon cycle and crop developmental model: description and evaluation against measurements of carbon fluxes and carbon stocks at several European agricultural sites, Agr. Ecosyst. Environ., 139, 402-418, doi:10.1016/j.agee.2010.06.012, 2010.

15 Tao, F., Zhang, Z., Liu, J., and Yokozawa, M.: Modelling the impacts of weather and climate variability on crop productivity over a large area: a new super-ensemble-based probabilistic projection, Agr. Forest Meteorol., 149, 1266-1278, doi:10.1016/j.agrformet.2009.02.015, 2009.

Taylor, K. E., Stouffer, R. J., and Meehl, G. A.: An overview of CMIP5 and the experiment design, B. Am. Meteorol. Soc., 93, 485-498, 2012.

Tulchinsky, T. H.: Micronutrient deficiency conditions: global health issues, Public Health Rev., 32, 243-255, 2010.

Urban, D., Roberts, M. J., Schlenker, W., and Lobell, D. B.: Projected temperature changes indicate significant increase in interannual variability of US maize yields, Climatic Change, 112, 525-533, 2012.

Waha, K., van Bussel, L., Müller, C., and Bondeau, A.: Climate driven simulation of global crop sowing dates, Global Ecol. Biogeogr., 21, 247-259, 2012.

Webber, H., Gaiser, T., and Ewert, F.: What role can crop models play in supporting climate change adaptation decisions to enhance food security in Sub-Saharan Africa?, Agr. Syst., 127, 161-177, 2014.

Wirsenius, S.: Human Use of Land and Organic Materials: Modeling the Turnover of Biomass in the Global Food System, PhD thesis, Chalmers University of Technology and University of Gothenburg, Gothenburg, Sweden, 2000.
ESDD

5, 1571-1606, 2014

\section{Optimizing cropland \\ cover for stable food production in \\ Sub-Saharan Africa}

P. Bodin et al.

\section{Title Page}

Abstract

Introduction

Conclusion

References

Tables

Figures

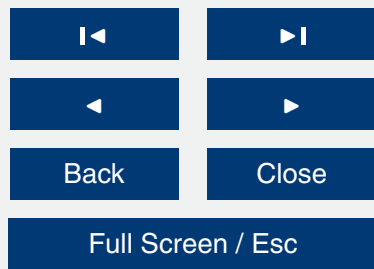

Printer-friendly Version

Interactive Discussion 
World Bank: World Development Indicators, World Bank, Washington, D.C., 2007.

Wramneby, A., Smith, B., Zaehle, S., and Sykes, M. T.: Parameter uncertainties in the modelling of vegetation dynamics - effects on tree community structure and ecosystem functioning in European forest biomes, Ecol. Model., 216, 277-290, 2008.

5 Wu, W., Shibasaki, R., Yang, P., Tan, G., Matsumura, K.-I., and Sugimoto, K.: Global-scale modelling of future changes in sown areas of major crops, Ecol. Model., 208, 378-390, 2007.

You, L., Crespo, S., Guo, Z., Koo, J., Ojo, W., Sebastian, K., Tenorio, M. T., Wood, S., and Wood-Sichra, U.: Spatial Produciton Allocation Model (SPAM) 2000 Version 3, Release 2,

\section{ESDD}

5, 1571-1606, 2014

Optimizing cropland cover for stable food production in Sub-Saharan Africa

P. Bodin et al.

Title Page

Abstract

Introduction

Conclusions

References

Tables

Figures

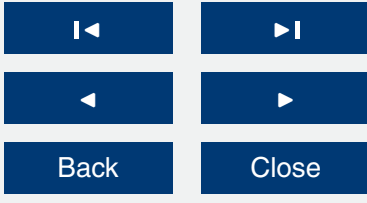

Full Screen / Esc

Printer-friendly Version

Interactive Discussion 


\section{ESDD}

$5,1571-1606,2014$

Optimizing cropland cover for stable food production in

Table 1. List of group of crops, or Crop Functional Types (CFT) included in the study. Listed are also which crops belong to each CFT.

\begin{tabular}{ll}
\hline CFT name & Crops included in CFT \\
\hline TeCo & Corn/Maize \\
(Temperate Corn) & Pulses \\
(Temperate Pulses) & Sugar beet, Potatoes \\
$\begin{array}{l}\text { TeSb } \\
\text { (Temperate Sugar beet) }\end{array}$ & Winter wheat, Spring wheat, Rye, Barley, Oats \\
TeWW & \\
(Temperate Winter Wheat) & Maniok/Cassava, Sweet potatoes \\
TrMa & \\
(Tropical Maniok) & Millet, Sorghum \\
TrMi & \\
(Tropical Millet) & Rice \\
TrRi & \\
(Tropical Rice) & \\
\hline
\end{tabular}

\section{Sub-Saharan Africa}

P. Bodin et al.

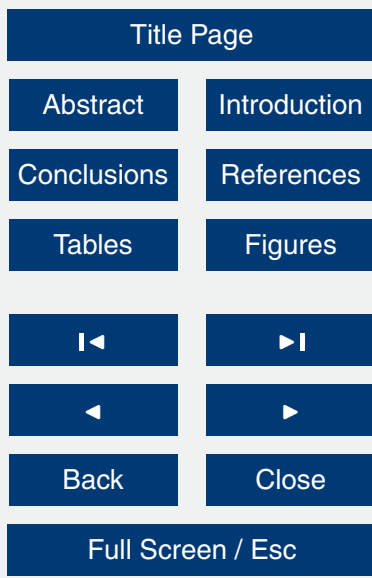

Printer-friendly Version

Interactive Discussion 
ESDD

$5,1571-1606,2014$

Optimizing cropland cover for stable food production in Sub-Saharan Africa

P. Bodin et al. distribution (Obs) and between the latitudinal mean of observed or optimized crop distribution and mean annual temperature (Tair) as well as annual precipitation (Precip). For clarity different correlation ranges are highlighted by using various combinations of italics, bold and underline (see bar below). Significant correlations $(p<0.001)$ are indicated by an asterisk $\left(^{*}\right)$.

\begin{tabular}{|c|c|c|c|c|c|c|c|c|c|c|c|c|}
\hline \multirow[b]{2}{*}{ CFT } & \multicolumn{4}{|c|}{ Obs } & \multicolumn{4}{|c|}{ Tair } & \multicolumn{4}{|c|}{ Prec } \\
\hline & $\mathrm{Opt}_{\mathrm{v}, \min }$ & $\mathrm{Opt}_{\mathrm{y}, \max }$ & $\mathrm{Opt}_{\mathrm{s}, \mathrm{crop}}$ & & Obs & $\mathrm{Opt}_{\mathrm{v}, \min }$ & $\mathrm{Opt}_{\mathrm{y}, \max }$ & $\mathrm{Opt}_{\mathrm{s}, \mathrm{crop}}$ & Obs & $\mathrm{Opt}_{\mathrm{v}, \min }$ & $\mathrm{Opt}_{\mathrm{y}, \max }$ & $\mathrm{Opt}_{\mathrm{s}, \mathrm{crop}}$ \\
\hline $\mathrm{TeCo}$ & $0.51^{*}$ & $0.53^{*}$ & -0.04 & & $-0.60^{*}$ & -0.11 & -0.18 & 0.29 & -0.26 & -0.12 & -0.14 & $0.31^{*}$ \\
\hline $\mathrm{TePu}$ & $0.34^{*}$ & $\overline{0.43}^{*}$ & 0.17 & & $0 . \overline{37}$ & -0.08 & 0.13 & $0.52^{*}$ & 0.19 & $-0.31^{*}$ & $-0.33^{*}$ & -0.10 \\
\hline $\mathrm{TeSb}$ & -0.03 & 0.18 & $0.58^{*}$ & & $-0.65^{*}$ & -0.05 & -0.37 & $-0.85^{*}$ & $-0.36^{*}$ & 0.22 & -0.08 & -0.78 \\
\hline TeWW & $0.78^{*}$ & $0.72^{*}$ & $\overline{-0.41}$ & & $-0.72^{*}$ & $-0.78^{*}$ & $-0.71^{*}$ & 0.24 & $-0.50^{*}$ & $-0.50^{*}$ & $-0.43^{*}$ & $0.30^{*}$ \\
\hline TrMa & $0.71^{*}$ & $0.81^{*}$ & $0.72^{*}$ & & $0.43^{*}$ & $0.33^{*}$ & $0.41^{*}$ & $0.74^{*}$ & $0.88^{*}$ & $\overline{0.70^{*}}$ & $\overline{0.79^{*}}$ & $0.81^{*}$ \\
\hline TrMi & $0.76^{*}$ & $0.71^{*}$ & -0.06 & & $0.71^{*}$ & $0.54^{*}$ & $0.36^{*}$ & -0.23 & -0.10 & -0.14 & -0.29 & -0.26 \\
\hline \multirow[t]{3}{*}{ TrRi } & 0.09 & 0.13 & 0.12 & & $0.38^{*}$ & $0.42^{*}$ & $0.48^{*}$ & 0.15 & 0.25 & $0.38^{*}$ & $0.44^{*}$ & $0.42^{*}$ \\
\hline & & & Obs & 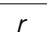 & $<0.0$ & $0.0-0.2$ & $0.2-0.4$ & $0.4-0.6$ & $0.6-0.8$ & 0.8 & & \\
\hline & & & Tair/Prec & $|r|$ & & $0.0-0.2$ & $0.2-0.4$ & $0.4-0.6$ & $0.6-0.8$ & 0.8 & & \\
\hline
\end{tabular}

Title Page

Abstract

Introduction

Conclusions

References

Tables

Figures

14

4

Back

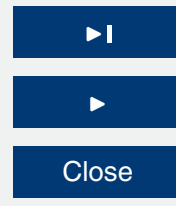

Full Screen / Esc

Printer-friendly Version

Interactive Discussion 


\section{ESDD}

$5,1571-1606,2014$

Optimizing cropland cover for stable food production in Sub-Saharan Africa

P. Bodin et al.

Table 3. Percent of grid cells where the optimized yield (or variance) is at least $25 \%$ larger (or smaller) compared to using current crop distribution for the three optimizations and three time periods.

\begin{tabular}{|c|c|c|c|c|c|c|c|c|c|}
\hline & \multicolumn{3}{|c|}{$\mathrm{Opt}_{\mathrm{v}, \text { min }}$} & \multicolumn{3}{|c|}{$\mathrm{Opt}_{\mathrm{y}, \max }$} & \multicolumn{3}{|c|}{$\mathrm{Opt}_{\mathrm{s}, \mathrm{crop}}$} \\
\hline & 1996-2005 & $2056-2065$ & 2081-2090 & 1996-2005 & $2056-2065$ & $2081-2090$ & 1996-2005 & 2056-2065 & $2081-2090$ \\
\hline $\begin{array}{l}\text { Difference in } \\
\text { yield }>25 \%\end{array}$ & $<1 \%$ & $<1 \%$ & $<1 \%$ & $13 \%$ & $25 \%$ & $29 \%$ & $85 \%$ & $87 \%$ & $88 \%$ \\
\hline $\begin{array}{l}\text { Difference in } \\
\text { variance }>25 \%\end{array}$ & $<1 \%$ & $<1 \%$ & $<1 \%$ & $0 \%$ & $20 \%$ & $24 \%$ & $91 \%$ & $92 \%$ & $92 \%$ \\
\hline
\end{tabular}

Title Page

Abstract

Introduction

Conclusions

References

Tables

Figures

14

Back

Full Screen / Esc

Printer-friendly Version

Interactive Discussion 
(a)
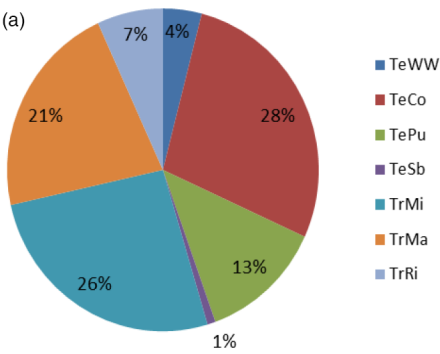

$$
\text { - TeCo }
$$$$
\text { - TePu }
$$$$
\text { - TeSb }
$$$$
\text { - TrMi }
$$$$
\text { n TrMa }
$$$$
\text { m TrRi }
$$

(c)

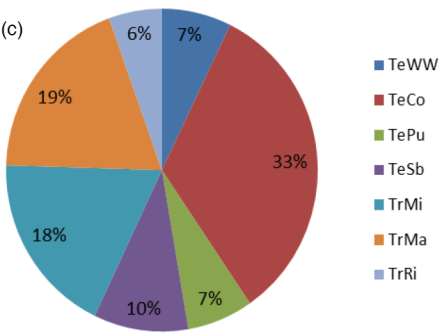

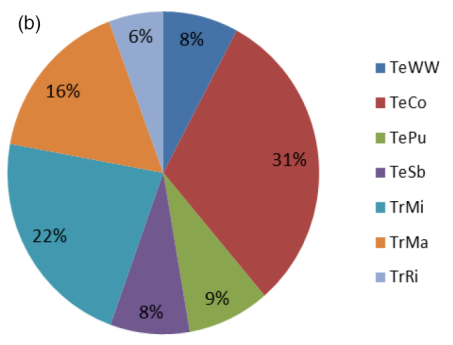

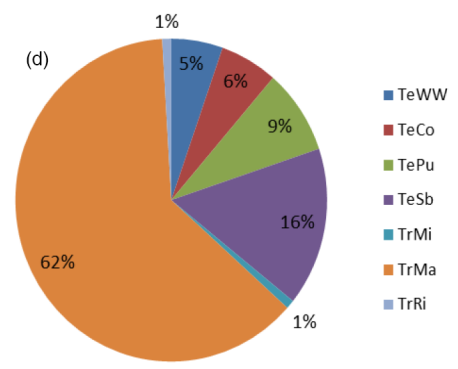

ESDD

5, 1571-1606, 2014

Optimizing cropland cover for stable food production in Sub-Saharan Africa

P. Bodin et al.

\section{Title Page}

Abstract

Introduction

Conclusions

References

Tables

Figures

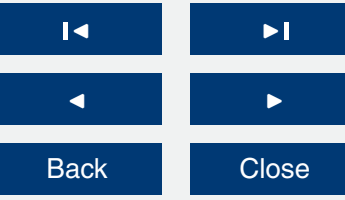

Full Screen / Esc

Printer-friendly Version

Interactive Discussion 

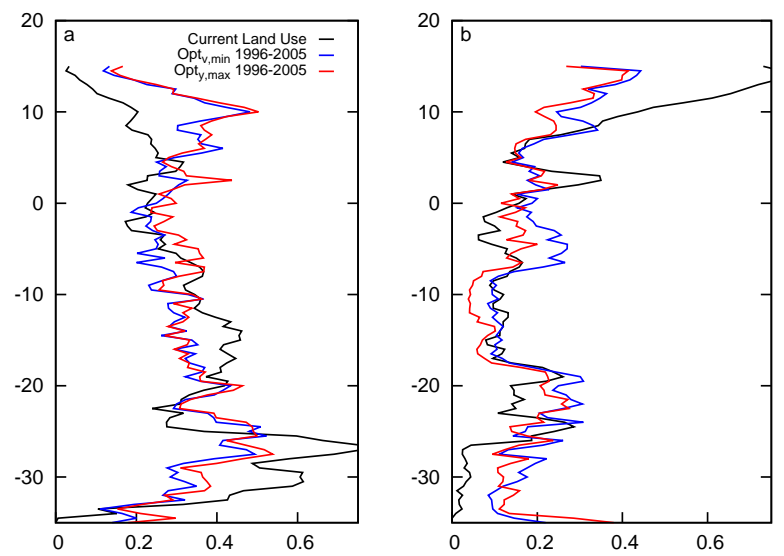

ESDD

5, 1571-1606, 2014

Optimizing cropland cover for stable food production in Sub-Saharan Africa

P. Bodin et al.
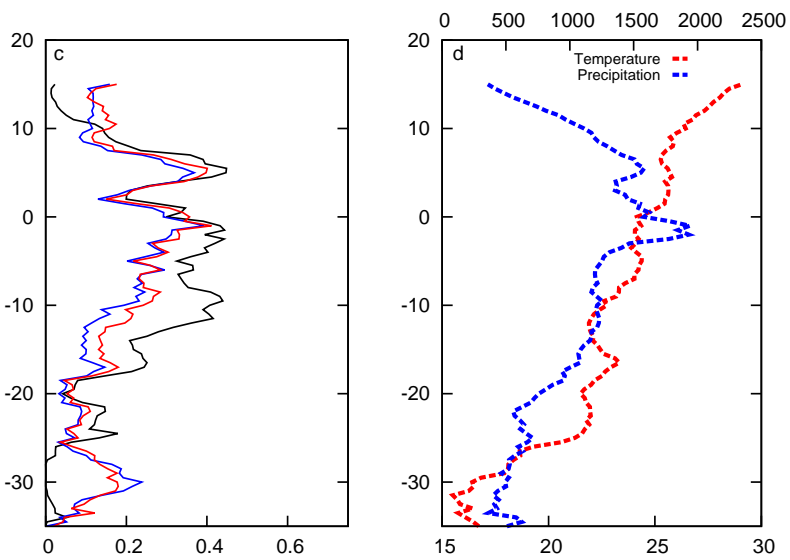

Title Page

Abstract

Introduction

Conclusions

References

Tables

Figures

14

4

Back

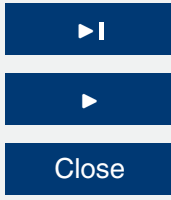

Full Screen / Esc

Figure 2. Optimized latitudinal mean crop distributions (a-c) for current climate (1996-2005) $\left(\right.$ Opt $_{v, \text { min }}$ solid blue lines; Opt $\mathrm{y,max}_{\text {max }}$ solid red lines) and observed crop distributions (black lines) for the three most common crops in SSA: TeCo (a), TrMi (b), and TrMa (c). The bottom right panel (d) represents latiudinal mean annual precipitation $(\mathrm{mm})$ (dotted blue line) and mean annual temperature $\left({ }^{\circ} \mathrm{C}\right)$ (dotted red line).

Printer-friendly Version

Interactive Discussion

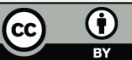



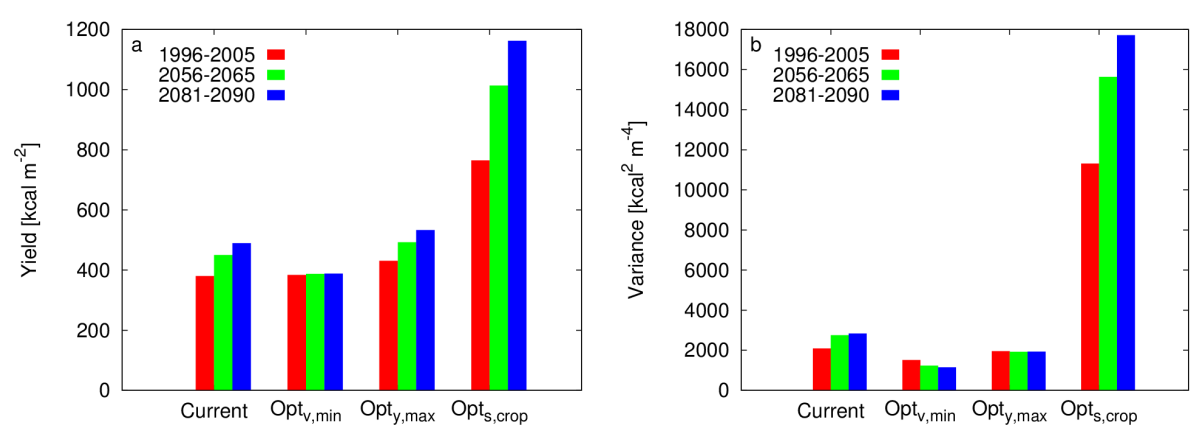

Figure 3. Grid cell median yield $\left(\mathrm{kcalm}^{-2}\right)$ optimized CFT fractions.

\section{ESDD}

5, 1571-1606, 2014

Optimizing cropland cover for stable food production in Sub-Saharan Africa

P. Bodin et al.

\section{Title Page}

Abstract

Introduction

Conclusions

References

Tables

Figures (a) and variance (b) $\left(\mathrm{kcal}^{2} \mathrm{~m}^{-4}\right)$ for current and

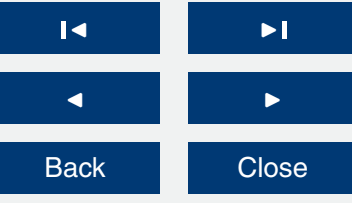

Full Screen / Esc

Printer-friendly Version

Interactive Discussion 


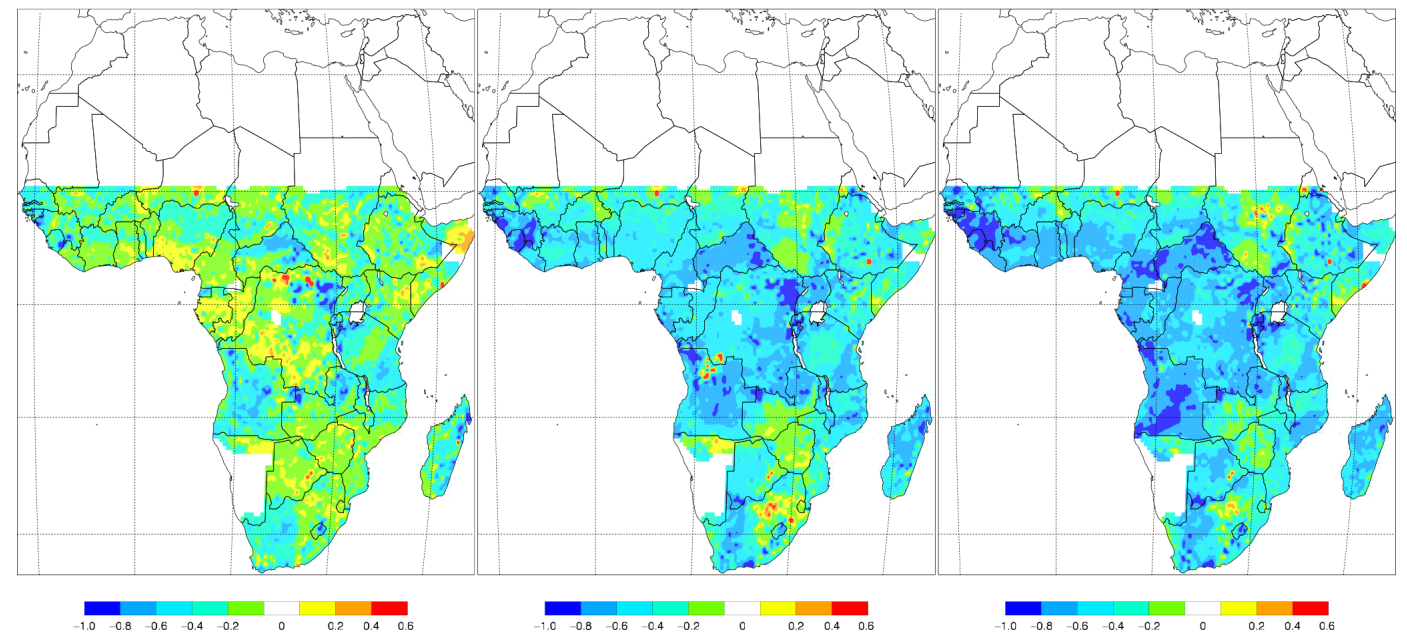

Figure 4. Relative difference in optimized variance compared to assuming current land use fractions for Opt $_{\mathrm{v}, \min }$ for the years 1996-2005 (a), 2056-2065 (b) and 2081-2090 (c).
ESDD

$5,1571-1606,2014$

Optimizing cropland cover for stable food production in Sub-Saharan Africa

P. Bodin et al.

\section{Title Page}

Full Screen / Esc

Printer-friendly Version

Interactive Discussion 


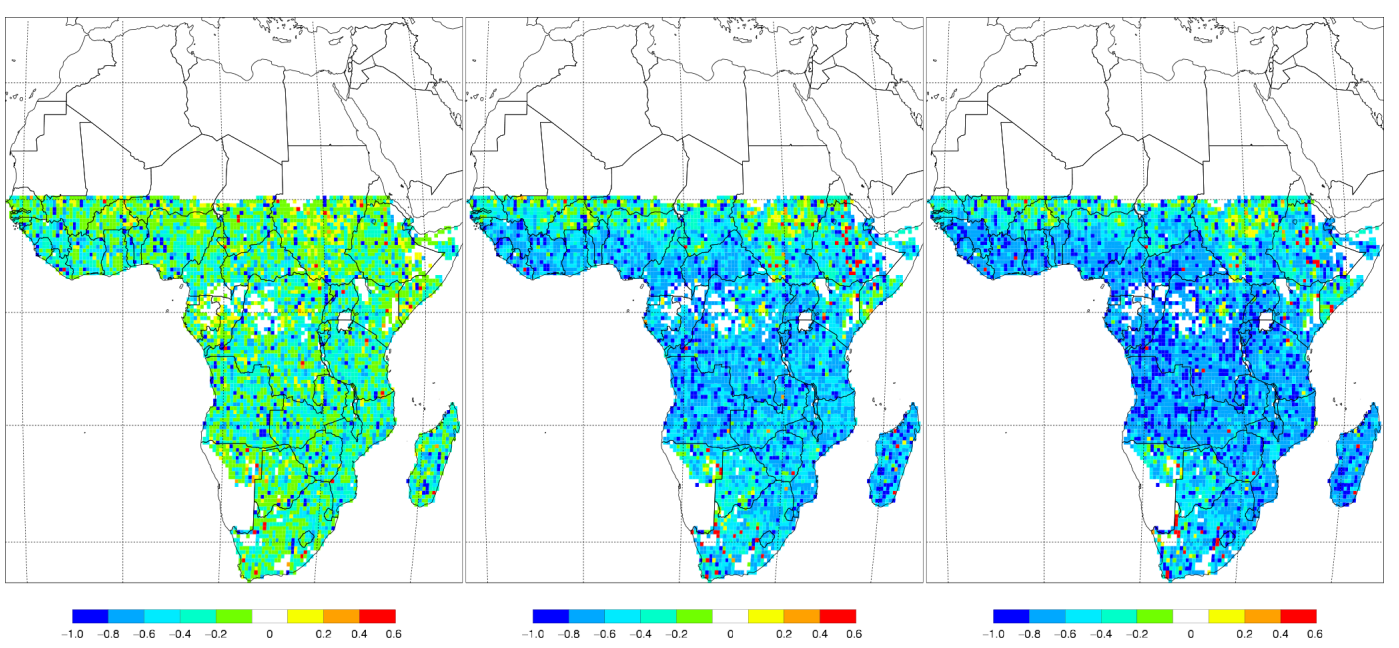

Figure 5. Relative difference in yield compared to assuming current land use fractions for Opt $_{\text {y,max }}$ for the years 1996-2005 (a), 2056-2065 (b) and 2081-2090 (c).

\section{ESDD}

$5,1571-1606,2014$

Optimizing cropland cover for stable food production in

\section{Sub-Saharan Africa}

P. Bodin et al.

\section{Title Page}

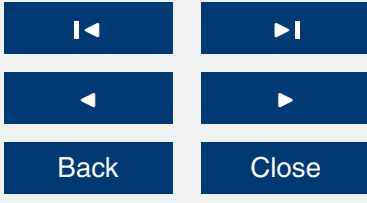

Full Screen / Esc

Printer-friendly Version

Interactive Discussion 